\title{
Evaluation of the Amount of Gas Generated through Combustion of Wood Charcoal and Agglomerated Charcoal Depending on Air Ventilation ${ }^{1}$
}

\author{
Young Min $\mathrm{JU}^{2,3} \cdot$ Hanseob $\mathrm{JEONG}^{2} \cdot$ Kwang-Seok $\mathrm{CHEA}^{2}$ • \\ Byung-Jun $\mathrm{AHN}^{2} \cdot$ Soo Min LEE(D) ${ }^{2, \dagger}$
}

\begin{abstract}
This study was conducted into combustion characteristics and gases generated by the combustion of charcoal and agglomerated charcoal distributed in the domestic using a combustion chamber based on the average space per crater of a charcoal-grilled restaurant in South Korea. Each of the three types of charcoals and agglomerated wood charcoals was analyzed for fuel and combustion characteristics. In addition, the concentration changes of $\mathrm{CO}_{2} \mathrm{CO}_{2}$, $\mathrm{NO}_{\mathrm{x}}$, and $\mathrm{O}_{2}$ were measured for 20 minutes depending on ventilation. As a result, $\mathrm{CO}$ yield without ventilation was measured in the range of 1390 to $4703 \mathrm{ppm}$, and $\mathrm{CO}$ yield with ventilation decreases about $29.8 \%$ to $57.4 \%$. $\mathrm{CO}_{2}$ yield without ventilation was measured in the range of $1.34 \%$ to $2.42 \%$, and $\mathrm{CO}_{2}$ yield was about $44.1 \%$ to $53.6 \%$ when the emission was more than about $1.5 \%$ at 10 minutes. The NOx yield was divided into two cases where the $\mathrm{NO}_{\mathrm{x}}$ yield was continuously increased because of incomplete combustion, emitted ranging from $29 \mathrm{ppm}$ to $47 \mathrm{ppm}$, and where emission was constant after 1 minute in the range of $9 \mathrm{ppm}$ to $18 \mathrm{ppm}$. The $\mathrm{NO}_{\mathrm{x}}$ yield with ventilation tends to be similar to the without ventilation, and $\mathrm{NO}_{\mathrm{x}}$ yield decreases up to $62.5 \%$. Therefore, it could be used for health risk assessment with the simulation of the usage environment of charcoal and agglomerated wood charcoal.
\end{abstract}

Keywords: charcoal, agglomerated charcoal, ventilation, combustion, gas emission

\section{INTRODUCTION}

Charcoal and Agglomerated charcoal, which are wood products designated by the Act on the Sustainable Use of Wood, are defined in 'Annex 14' and 'Annex 15' of 'Specifications and Quality Standards for Wood Products' of National Institute of Forest
Science Notice No. 2018-8 (Korea Forest Service, 2018). The charcoal is classified into white charcoal and black charcoal based on the refining method; one is cooled down outside a charcoal kiln (white charcoal) and the other one is cooled down inside a charcoal kiln (black charcoal). Agglomerated charcoal is classified into agglomerated charcoal with charcoal

\footnotetext{
${ }^{1}$ Date Received September 14, 2020, Date Accepted October 23, 2020

2 Division of Wood Chemistry, Department of forest Products, National Institute of Forest Science, Seoul 02455, Republic of Korea

${ }^{3}$ Department of Mechanical Engineering, Korea University, Seoul 02841, Republic of Korea

$\dagger$ Corresponding author: Soo Min LEE (e-mail: lesoomin@korea.kr, ORCID: 0000-0002-4214-5094)
} 
powder, agglomerated charcoal with sawdust, and ignition-type of perforated charcoal based on whether a charcoal contains bonding and ignition agents and the way in which the charcoal is agglomerated (National Institute of Forest Science, 2018).

Charcoal and agglomerated charcoal have the advantage of having higher energy density than wood, burning for a long time, and producing less gas (Kabir et al., 2010; Huang et al., 2016). In addition, they can be produced using a variety of raw materials such as bark, sawdust, and coconut shells, and have the advantage of being relatively low in sulfur and mercury content than coal along with easier storage and maintenance (Jelonek et al., 2020; Vicente et al., 2018). Because of these advantages, the charcoal and agglomerated charcoal are widely used in cooking, especially for barbeques where meat is cooked by charcoal fire and consumed in both indoors and outdoors. However, the process of igniting the charcoal and the exhaustfrom the barbecue through high-temperature charcoal fire can degrade the air quality and be absorbed into the food. As a result, consumers are likely to be exposed to pollutants when consuming the meat or breathing (Kabir et al., 2010; Huang et al., 2016).

The 'Specifications and Quality Standards for Wood Products' notice specifies fuel characteristics such as moisture content, ash, higher heating value, and fixed carbon as quality items for charcoal and agglomerated charcoal. In addition, since the agglomerated charcoal contains chemical substances such as bonding and ignition agents, five heavy metals such as lead, arsenic, mercury, and cadmium and elements such as chromium, copper, nickel, and sulfur are included in the quality category (Korea Forest Service, 2018). However, the category for the heavy metals indicate the amount of heavy metals in the product before use, and the standards for the type and hazardousness of the combustion gases generated are insufficient, when a consumer uses the product for roasting.
In the results of international studies that analyzed the emissions of charcoal and agglomerated charcoal combustion, it was reported that the concentration of mercury was relatively high in the flue gas from burning charcoal (Pandey et al., 2009), and carcinogenic substances such as formaldehyde, acetaldehyde and some elements were also reported in some products (Huang et al., 2016). In addition, it has been reported that fine particles, carbon monoxide, carbon dioxide, and nitrogen oxides that can enter a human body during the breathing process are continuously generated during the combustion of charcoal (Kabir et al., 2010).

In short, it is judged that there are various gas components produced from the combustion of charcoal and agglomerated charcoal, and these results are anticipated to be crucial supplement data in judging and evaluating the safety of use of the products. However, for the charcoal and agglomerated charcoal products in Korea, systematic data on the types and concentrations of the flue gas produced during such use is still insufficient.

Therefore, in this study, the condition was limited to an occasion which the charcoal and agglomerated charcoal are used for cooking, and the concentration of flue gas during the combustion $\left(\mathrm{CO}, \mathrm{CO}_{2}, \mathrm{NO}_{\mathrm{x}}, \mathrm{O}_{2}\right)$ is measured in real time to compare and analyze the change in the concentration of the gases according to the ventilation volume, considering the environment of restaurants in Korea using charcoal and agglomerated charcoal.

\section{MATERIALS and METHODS}

\subsection{Test materials}

In this study, 3 types of charcoal and agglomerated charcoal each, which are widely used in Korea, were purchased, and used as test materials. The charcoals which were used were 2 types; white charcoal (A1, 
Evaluation of the Amount of Gas Generated through Combustion of Wood Charcoal and Agglomerated Charcoal Depending on Air Ventilation

Table 1. Product information of charcoal and agglomerated charcoal

\begin{tabular}{|c|c|c|c|c|}
\hline Sample & Species & Raw material & $\begin{array}{l}\text { Country of } \\
\text { origin }\end{array}$ & Additives \\
\hline A1 & White charcoal 1 & Oak & Vietnam & - \\
\hline A2 & White charcoal 2 & Oak & Laos & - \\
\hline A3 & Black charcoal & Oak & South Korea & - \\
\hline B1 & $\begin{array}{l}\text { Agglomerated charcoal with charcoal } \\
\text { powder }\end{array}$ & undeclared & USA & $\begin{array}{c}\text { Corn starch : } 15 \% \\
\text { limestone : } 7 \% \\
\text { borax : } 1.5 \% \\
\text { barium nitrate : } 0.1 \%\end{array}$ \\
\hline B2 & Ignition-type of perforated charcoal & undeclared & South Korea & $\begin{aligned} \text { barium nitrate } & : 13 \% \\
\text { Wheat flour }: & 5 \% \\
\text { Sodium nitrate }: & 3.5 \%\end{aligned}$ \\
\hline B3 & Agglomerated charcoal with sawdust & Broad-leaved tree & Indonesia & - \\
\hline
\end{tabular}

A2) and 1 type of black coal (A3), and for agglomerated charcoal, 1 type of agglomerated charcoal with charcoal powder (B1), 1 type of Ignition-type of perforated charcoal (B2), and 1 type of agglomerated charcoal with sawdust (B3) were used, and Table 1 shows the characteristics of the product at the time of purchase in the product quality labeling.

\subsection{Fuel characteristic analysis}

Proximate analysis as performed to compare the fuel characteristics of the test materials, and the ultimate analysis and higher heating value are measured. Detailed measurement methods can be found in $\mathrm{Ju}$ et al. (2020). The higher heating value of the sample was measured using a bomb calorimeter (6400 Automatic Isoperibol Calorimeter, Parr Instrument company, USA), and a powder sample of about $0.5 \mathrm{~g}$ was accurately measured and used as the analysis sample.

Proximate analysis was performed using an Thermogravimetric analyzer (PrepASH229, precisa, Swiss) to analyze the moisture content, volatile content, and ash content of the sample, and the fixed carbon was calculated by using Equation (1).

$$
\mathrm{FC}=100-(\mathrm{MC}+\mathrm{VM}+\mathrm{ASH})
$$

FC: Fixed carbon (\%)

MC: Moisture content (\%)

VM: Volatile matter (\%)

Ash: Ash content (\%)

Standard material 2693 (NIST, USA) was used for ultimate analysis, and the contents of carbon, hydrogen, nitrogen, and sulfur were analyzed using an element analyzer (vario MICRO cube elemental analyzer, elementar, Germany), and the oxygen content was calculated by using Equation (2).

$$
\mathrm{O}=100-(\mathrm{C}+\mathrm{H}+\mathrm{N}+\mathrm{S})
$$
O: Oxygen content (\%)
C: Carbon content $(\%)$
$\mathrm{H}$ : Hydrogen content (\%)
$\mathrm{N}$ : Nitrogen content (\%)
S: Sulfur content $(\%)$

\subsection{Combustion testing method undersimulated use environment}

A schematic diagram of a combustion chamber made for the combustion testing of charcoal and agglomerated charcoal is shown in Fig. 1. The combustion 


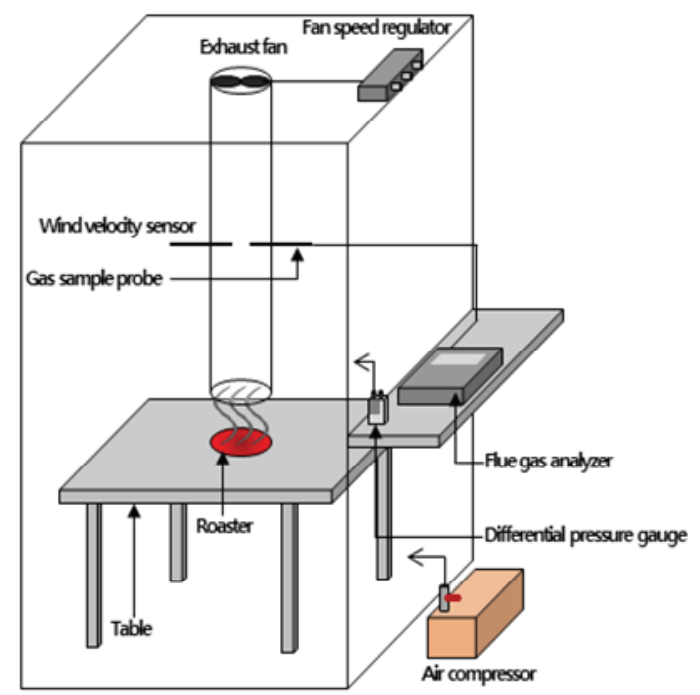

Fig. 1. Scheme of combustion chamber.

combustion chamber was designed as $1.5 \times 1.5 \times 2 \mathrm{~m}$ as width $\times$ length $\times$ height respectively, assuming a table space for 4 people of a typical charcoal restaurant, and the internal volume was about $3.96 \mathrm{~m}^{3}$.

The height of the table is $720 \mathrm{~mm}$, the distance between the roaster and the exhaust port is $120 \mathrm{~mm}$, and the distance between the exhaust port (inner diameter: $95 \mathrm{~mm}$, height: $1 \mathrm{~m}$ ) and the table is $120 \mathrm{~mm}$. The measuring equipment, an anemometer and gas measurement probe, were installed in the center (height direction) of the exhaust port, and a ventilation fan was installed at the top of the exhaust port, and the speed of the ventilation fan was adjusted through a fan speed controller.

The exhaust velocity measured by the gas measurement probe was $0.3 \mathrm{~m} / \mathrm{s}$, and the air volume was 0.008 $\mathrm{m}^{3} / \mathrm{s}$. When the ventilation fan was operated, external air was constantly introduced into the air compressor at a rate of $25 \mathrm{~L} / \mathrm{min}$ through a $6 \mathrm{~mm}$ diameter tube for air circulation inside the model chamber. The gas sampling tube was installed in the center of the combustion chamber, $1 \mathrm{~m}$.

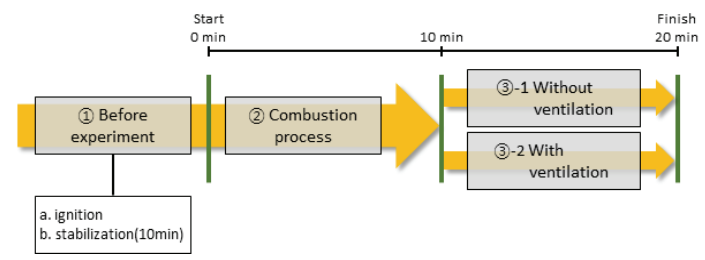

Fig. 2. Process for combustion of charcoal and agglomerated charcoal.

The test process that simulated the environment of a general domestic restaurant using charcoal is shown in Fig. 2. To simulate the situation in which charcoal was ignited by an external igniter and used for roasting, the test sample was first ignited outside the model chamber and then burned for 10 minutes (Fig. 2 (1)).

After that, the test sample was put into the model chamber and sealed, and the gas emissions and temperature were measured. First, the sample was burned for 10 minutes to accumulate flue gas inside the combustion chamber (Fig. 2 (2)). Second, the change in the concentration of exhaust gas with ventilation was measured for 10 minutes with two cases; with and without the ventilation (Fig. 2 (3)-1, 2). After the end of the test, the weight of the test sample, which was burned for 30 minutes, was measured, and the weight of the remaining residue after spontaneous combustion in the atmosphere was measured.

\subsection{Flue gas measurement}

The real-time emissions of exhaust gas generated from the combustion of charcoal and agglomerated charcoal were measured using a flue gas analyzer (Testo 350XL, Testo, Germany). A gas measurement probe installed in the center of the exhaust port was used to measure the yield of $\mathrm{CO}, \mathrm{CO}_{2}, \mathrm{NO}_{\mathrm{x}}$, and $\mathrm{O}_{2}$ at intervals of 15 seconds for 20 minutes. 
Evaluation of the Amount of Gas Generated through Combustion of Wood Charcoal and Agglomerated Charcoal Depending on Air Ventilation

\section{RESULTS and DISCUSSION}

\subsection{Fuel characteristics}

The results of analyzing the fuel characteristics of charcoal and agglomerated charcoal are shown in Table 2. As a result of the proximate analysis, in terms of moisture content, charcoal products $\mathrm{A} 1 \sim \mathrm{A} 3$ were $0.9 \sim 1.9 \%$, and agglomerated charcoal products $\mathrm{B} 1 \sim \mathrm{B} 3$ were 2.6 3.0\%, which all met the standard of Annex 14 (agglomerated charcoal) and Annex 15 (charcoal) of 'Specifications and Quality Standards for Wood Products', Notice No. 2018-8 by National institute of forest science (National institute of forest science, 2018). Volatile compounds showed the highest level with $43.3 \%$ in $\mathrm{B} 1$ and the lowest with $5.4 \%$ in $\mathrm{A} 2$. As for the ash content, B2 was $39.3 \%$, which was $22.7 \%$ higher than the quality standard of $17 \%$ of Ignition-type of perforated charcoal, which did not sat- isfy the quality standard. Such a result may be attributed to the fact that substances which can degrade quality such as soil are included during a raw material processing (Ju et al., 2020; Jeoung et al., 2020). On the other hand, all other products showed results that satisfied the quality standard. In the case of charcoal, there was no quality standard for the fixed carbon content, and A1, A2, and A3 showed 86.0\%, 90.4\%, and $57.7 \%$, respectively.

In the case of the agglomerated charcoal, B1 and B3 satisfied the quality standard, but B2 was at $26.8 \%$, which was $23.2 \%$ lower than the quality standard. Based on a result of ultimate analysis, the carbon content was the highest with $97.4 \%$ in A2 and the lowest with $40.6 \%$ in B2, and as carbon content increased, the hydrogen, nitrogen and oxygen content decreased. In previous studies, it was reported that hydrogen and oxygen level decreased as carbon in charcoal increased (Jo et al., 2007; Lee et al., 2010). On the contrary, it showed

Table 2. Proximate analysis, ultimate analysis, and High heating value (HHV) of charcoals and agglomerated charcoal

\begin{tabular}{|c|c|c|c|c|c|c|c|c|c|c|}
\hline \multirow{2}{*}{ Sample } & \multicolumn{4}{|c|}{$\begin{array}{l}\text { Proximate analysis } \\
\text { (wt.\%, dry basis) }\end{array}$} & \multicolumn{5}{|c|}{$\begin{array}{l}\text { Ultimate analysis } \\
\text { (wt.\%, dry basis) }\end{array}$} & \multirow{2}{*}{$\begin{array}{c}\text { HHV } \\
\text { (kcal/kg, } \\
\text { dry basis) }\end{array}$} \\
\hline & Moisture & $\begin{array}{l}\text { Volatile } \\
\text { matter }\end{array}$ & Ash & $\begin{array}{c}\text { Fixed } \\
\text { carbon }^{1)}\end{array}$ & $\mathrm{C}$ & $\mathrm{H}$ & $\mathrm{N}$ & $\mathrm{O}^{2)}$ & $\mathrm{S}$ & \\
\hline Al & $\begin{array}{c}1.9 \\
(0.1)^{3)}\end{array}$ & $\begin{array}{c}9.4 \\
(0.2)\end{array}$ & $\begin{array}{c}2.8 \\
(0.0)\end{array}$ & $\begin{array}{l}86.0 \\
(0.3)\end{array}$ & $\begin{array}{l}96.5 \\
(0.5)\end{array}$ & $\begin{array}{c}0.90 \\
(0.06)\end{array}$ & $\begin{array}{c}0.80 \\
(0.07)\end{array}$ & $\begin{array}{c}1.77 \\
(0.51)\end{array}$ & $\begin{array}{c}0.00 \\
(0.00)\end{array}$ & $\begin{array}{c}7,777 \\
(46)\end{array}$ \\
\hline $\mathrm{A} 2$ & $\begin{array}{c}1.8 \\
(0.1)\end{array}$ & $\begin{array}{c}5.4 \\
(0.2)\end{array}$ & $\begin{array}{c}2.4 \\
(0.6)\end{array}$ & $\begin{array}{l}90.4 \\
(0.5)\end{array}$ & $\begin{array}{l}97.4 \\
(0.2)\end{array}$ & $\begin{array}{c}0.51 \\
(0.02)\end{array}$ & $\begin{array}{c}0.74 \\
(0.07)\end{array}$ & $\begin{array}{c}1.29 \\
(0.20)\end{array}$ & $\begin{array}{c}0.00 \\
(0.00)\end{array}$ & $\begin{array}{l}7,780 \\
(9)\end{array}$ \\
\hline A3 & $\begin{array}{c}0.9 \\
(0.0)\end{array}$ & $\begin{array}{l}39.6 \\
(0.2)\end{array}$ & $\begin{array}{l}1.8 \\
(0.1)\end{array}$ & $\begin{array}{l}57.7 \\
(0.2)\end{array}$ & $\begin{array}{l}76.6 \\
(0.2)\end{array}$ & $\begin{array}{c}3.99 \\
(0.06)\end{array}$ & $\begin{array}{c}0.44 \\
(0.01)\end{array}$ & $\begin{array}{l}18.92 \\
(0.26)\end{array}$ & $\begin{array}{c}0.01 \\
(0.00)\end{array}$ & $\begin{array}{c}6,954 \\
(15)\end{array}$ \\
\hline B1 & $\begin{array}{c}2.9 \\
(0.5)\end{array}$ & $\begin{array}{l}43.3 \\
(0.2)\end{array}$ & $\begin{array}{l}12.1 \\
(0.1)\end{array}$ & $\begin{array}{l}41.6 \\
(0.4)\end{array}$ & $\begin{array}{l}60.9 \\
(0.7)\end{array}$ & $\begin{array}{c}4.19 \\
(0.14)\end{array}$ & $\begin{array}{c}0.30 \\
(0.02)\end{array}$ & $\begin{array}{l}34.62 \\
(0.79)\end{array}$ & $\begin{array}{c}0.00 \\
(0.00)\end{array}$ & $\begin{array}{c}5,428 \\
(53)\end{array}$ \\
\hline B2 & $\begin{array}{l}3.0 \\
(0.1)\end{array}$ & $\begin{array}{l}30.3 \\
(2.4)\end{array}$ & $\begin{array}{l}39.9 \\
(1.7)\end{array}$ & $\begin{array}{l}26.8 \\
(1.2)\end{array}$ & $\begin{array}{l}40.6 \\
(1.0)\end{array}$ & $\begin{array}{c}1.76 \\
(0.06)\end{array}$ & $\begin{array}{c}2.77 \\
(0.13)\end{array}$ & $\begin{array}{l}54.83 \\
(1.00)\end{array}$ & $\begin{array}{c}0.05 \\
(0.00)\end{array}$ & $\begin{array}{l}3,565 \\
(144)\end{array}$ \\
\hline B3 & $\begin{array}{c}2.6 \\
(0.1)\end{array}$ & $\begin{array}{l}11.5 \\
(0.4)\end{array}$ & $\begin{array}{c}4.7 \\
(0.1)\end{array}$ & $\begin{array}{l}81.2 \\
(0.2)\end{array}$ & $\begin{array}{l}88.8 \\
(0.3)\end{array}$ & $\begin{array}{c}2.12 \\
(0.10)\end{array}$ & $\begin{array}{c}0.32 \\
(0.01)\end{array}$ & $\begin{array}{c}8.77 \\
(0.23)\end{array}$ & $\begin{array}{c}0.00 \\
(0.00)\end{array}$ & $\begin{array}{c}7,592 \\
(10)\end{array}$ \\
\hline
\end{tabular}

\footnotetext{
1) Fixed carbon $(\%)=100-($ Moisture + Volatile matter + Ash $)(\%)$

2) $\mathrm{O}(\%)=100-(\mathrm{C}+\mathrm{H}+\mathrm{N}+\mathrm{S})(\%)$

3) The numbers in parenthesis refer to standard deviations.
} 
a proportional relationship with the higher heating value, because $\mathrm{C}-\mathrm{C}$ bonding of high bonding energy increases with the degree of carbonization (Lee et al., 2016).

In case of sulfur, the sulfur content was $0.01 \%$ and $0.05 \%$ in $\mathrm{A} 2$ and $\mathrm{B} 2$, respectively. For the higher heating value, B2 did not satisfy the quality standard of $5,500 \mathrm{kcal} / \mathrm{kg}$, similar to the case of Ash and fixed carbon.

\subsection{Ignition time and weight change during combustion}

The combustion characteristics performed in the chamber according to the ventilation are shown in Table 3. The ignition time was different depending on the type of charcoal and agglomerated charcoal, ventilation, and an igniting agent. On average, the charcoals (A1, A2, A3) showed a longer ignition time than the agglomerated charcoal, which may be attributed to a lack of low molecular compounds that are pronefor ignition due to low volatile compounds (Chia et al., 2014). In particular, among the agglomerated charcoal, the ignition time was the shortest at 3 minutes for $\mathrm{B} 1$ and
B2 with igniting agents added. However, in the case of B3 without the igniting agent, the ignition time was 15 minutes, which was about 5 times longer than that of $\mathrm{B} 1$ and $\mathrm{B} 2$. As a result, it was confirmed that the ignition performance of the agglomerated charcoal was greatly improved by the igniting agent.

When the agglomerated charcoal and charcoal were burned without ventilation, the content of volatile matter was relatively higher than that with ventilation in all samples except for the case of B2. In particular, in the case of B1, the content of volatile matter was the highest in both with and without ventilation; $68.9 \%$ and $67.8 \%$, respectively. After leaving it in the atmosphere environment, the content of the residue after combustion was generally high without ventilation, but the tendency was different for some products. It is considered that the possibility of incomplete combustion increases as oxygen supply required for combustion is limited without ventilation, and accordingly, the amount of residues after the combustion has increased compared to the ventilated condition. The lowest residual content was $6.1 \%$ and $3.2 \%$ respectively in $\mathrm{A} 1$ and $\mathrm{A} 3$ with ventilation.

Table 3. Combustion characteristics of charcoal and agglomerated charcoal in a closed and ventilated condition

\begin{tabular}{|c|c|c|c|c|c|}
\hline Sample & Condition & $\begin{array}{l}\text { Ignition time } \\
(\mathrm{min})\end{array}$ & $\begin{array}{l}\text { Volatile matter } \\
\text { (wt.\%) }\end{array}$ & $\begin{array}{l}\text { Burned material content } \\
\text { for } 30 \mathrm{~min}(\%)\end{array}$ & $\begin{array}{c}\text { Residual } \\
(\%)\end{array}$ \\
\hline Al & \multirow{6}{*}{ closed } & 12 & 9.4 & 54.7 & 13.2 \\
\hline $\mathrm{A} 2$ & & 9 & 5.4 & 34.9 & 30.8 \\
\hline A3 & & 8 & 39.6 & 60.5 & 12.8 \\
\hline B1 & & 3 & 43.3 & 68.9 & 25.9 \\
\hline B2 & & 3 & 30.3 & 53.7 & 37.2 \\
\hline B3 & & 15 & 11.5 & 39.4 & 6.4 \\
\hline $\mathrm{A} 1$ & \multirow{6}{*}{ ventilated } & 12 & 9.4 & 52.8 & 6.1 \\
\hline $\mathrm{A} 2$ & & 9 & 5.4 & 38.4 & 33.8 \\
\hline A3 & & 8 & 39.6 & 59.4 & 3.2 \\
\hline B1 & & 3 & 43.3 & 67.8 & 11.0 \\
\hline B2 & & 3 & 30.3 & 59.7 & 33.2 \\
\hline B3 & & 15 & 11.5 & 33.3 & 19.8 \\
\hline
\end{tabular}


Evaluation of the Amount of Gas Generated through Combustion of Wood Charcoal and Agglomerated Charcoal Depending on Air Ventilation

\subsection{Real-time flue gas emissions}

The results of measuring the concentrations of $\mathrm{CO}$, $\mathrm{CO}_{2}, \mathrm{NO}_{\mathrm{x}}$, and $\mathrm{O}_{2}$ emitted through the combustion of charcoal and agglomerated charcoal in real time are shown in Fig. 3, 4, 5, and 6, and the hazard criteria of each $\mathrm{CO}$ and $\mathrm{NO}_{\mathrm{x}}$ are shown in Table 4. The concentration level of $\mathrm{O}_{2}$ without ventilation is shown in Fig. 3 as a solidline. On average, it decreased from $21.04 \%$ ( 0 minute) to $17.5 \%$. It continued to decrease over time from the beginning, and at 20 minutes, A1, $\mathrm{A} 2, \mathrm{~A} 3, \mathrm{~B} 1, \mathrm{~B} 2$, and $\mathrm{B} 3$ decreased by up to $18.8 \%$,

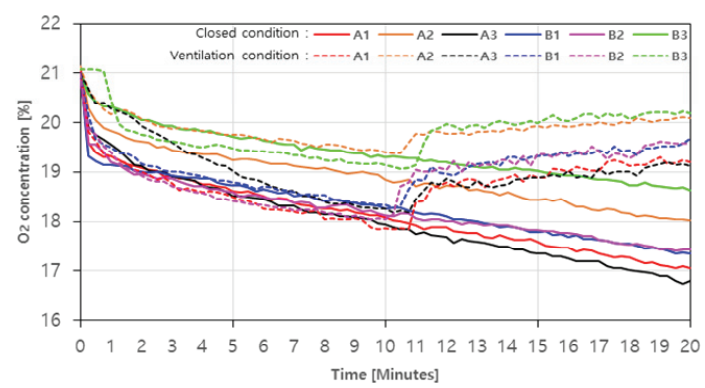

Fig. 3. $\mathrm{O}_{2}$ concentration of charcoal and agglomerated charcoal with and without ventilation (A1 : white charcoal 1, A2 : white charcoal 2, A3 : black charcoal, B1 : Agglomerated charcoal with charcoal powder, B2 : Ignition-type of perforated charcoal, B3 : Agglomerated charcoal with sawdust).

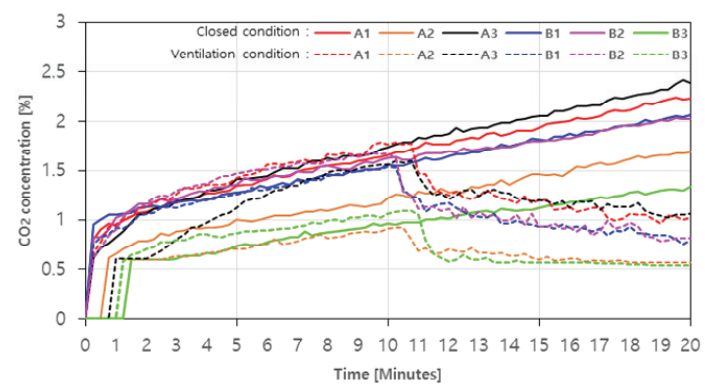

Fig. 5. $\mathrm{CO}_{2}$ concentration of charcoal and agglomerated charcoal with and without ventilation (A1 : white charcoal 1, A2 : white charcoal 2, A3 : black charcoal, B1 : Agglomerated charcoal with charcoal powder, B2 : Ignition-type of perforated charcoal, B3 : Agglomerated charcoal with sawdust).
$14.8 \%, 20.0 \%, 17.8 \%, 17.0 \%$, and $11.4 \%$, respectively (Fig. 3). The $\mathrm{O}_{2}$ concentration level with ventilation is shown in Fig. 3 as a solid line. The $\mathrm{O}_{2}$ concentration level rapidly increased after the ventilation fan was operated, and the level was recovered to $91.2 \sim 96.0 \%$ of the initial concentration within this experiment range.

For $\mathrm{CO}$, the concentration without ventilation is shown in Fig. 4 as a solid line. The concentration level showed a tendency to continuously increase as the combustion time elapsed. The agglomerated charcoal (B1, B2, B3) showed relatively higher CO concentration

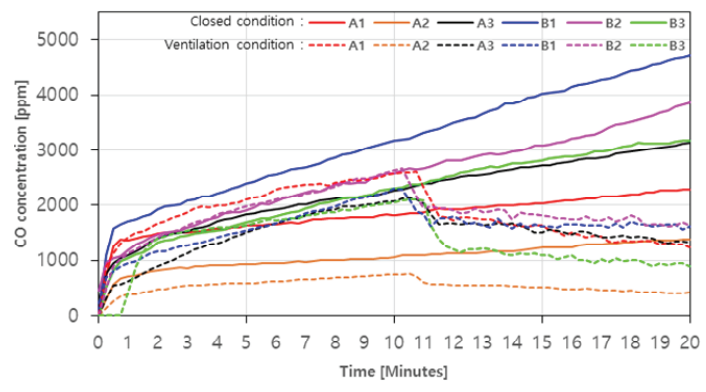

Fig. 4. CO concentration of charcoal and agglomerated charcoal with and without ventilation (A1 : white charcoal 1, A2 : white charcoal 2, A3 : black charcoal, B1 : Agglomerated charcoal with charcoal powder, B2 : Ignition-type of perforated charcoal, B3 : Agglomerated charcoal with sawdust).

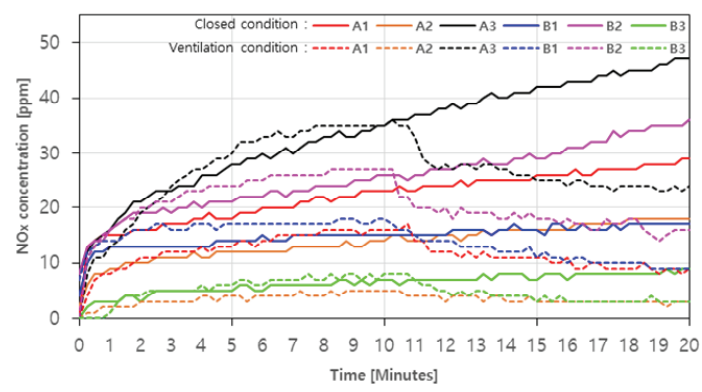

Fig. 6. $\mathrm{NO}_{\mathrm{x}}$ concentration of charcoal and agglomerated charcoal with and without ventilation (A1 : white charcoal 1, A2 : white charcoal 2, A3 : black charcoal, B1 : Agglomerated charcoal with charcoal powder, B2 : Ignition-type of perforated charcoal, B3 : Agglomerated charcoal with sawdust). 
Table 4. Effluent quality standard of air pollutants (The minister of environment, 2020)

\begin{tabular}{ccc}
\hline $\begin{array}{c}\text { Air } \\
\text { pollutant }\end{array}$ & $\begin{array}{c}\text { Facility of air } \\
\text { pollutant }\end{array}$ & $\begin{array}{c}\text { Effluent quality } \\
\text { standard }\end{array}$ \\
\hline \hline \multirow{2}{*}{$\mathrm{CO}$} & $\begin{array}{c}\text { Facility of using biomass } \\
\text { of wood pellet }\end{array}$ & $\begin{array}{c}\text { less than } \\
200 \mathrm{ppm}\end{array}$ \\
\hline \multirow{2}{*}{$\mathrm{NO}_{\mathrm{x}}$} & $\begin{array}{c}\text { Facility of using biomass } \\
\text { of wood pellet }\end{array}$ & $\begin{array}{c}\text { less than } \\
90 \mathrm{ppm}\end{array}$ \\
\hline
\end{tabular}

level than the charcoal during the combustion. Especially, B1 showed the highest level of $4703 \mathrm{ppm}$ (20 minutes) among the agglomerated charcoal, and 1390 ppm, the lowest in A2 among the charcoals.

In case with ventialtion, the concentration level of $\mathrm{CO}$ decreased rapidly after 10 minutes, which was the starting point of the ventilation fan operation, and then gradually decreased in all samples (Fig. 4. dotted line). It is assumed that as the amount of $\mathrm{CO}$ produced decreased as the concentrated $\mathrm{CO}$ in the combustion chamber was vented out, and a complete combustion occurred with the inflowed air over time.

Particularly, in the case of $\mathrm{B} 3$, the maximum reduction rate (about $57.4 \%$ ) was shown as the $\mathrm{CO}$ concentration level decreased from $2102 \mathrm{ppm}$ to $896 \mathrm{ppm}$ with ventilation, while the reduction of $\mathrm{B} 1$ was the lowest at $29.8 \%$. In addition, the average CO concentration was 3092.7 ppm (20 minutes) in closed condition and $1189.2 \mathrm{ppm}$ (20 minutes) with ventilation, which did not satisfy the emission limit of $200 \mathrm{ppm}$. This indicates that when using charcoal and agglomerated charcoal, a ventilated space is required rather than a closed space, and ventilation should be used with a ventilation volume higher than $0.008 \mathrm{~m}^{3} / \mathrm{s}$.

In the case of $\mathrm{CO}_{2}$, the concentration was in the low range of $2.5 \%$ or less, but both with and without ventilation were similar to the trend of $\mathrm{CO}$ concentration level change (Fig. 5). In case with ventialtion, $\mathrm{CO}_{2}$ production amount of $\mathrm{A} 1, \mathrm{~A} 2, \mathrm{~A} 3, \mathrm{~B} 1, \mathrm{~B} 2$, and B3 was $2.23 \%, 1.69 \%, 2.42 \%, 2.07 \%, 2.03 \%$ and $1.34 \%$, respectively (Fig. 5. Solid line), which were proportional to the aforementioned decrease in $\mathrm{O}_{2}$ concentration level. In previous studies, it was reported that the inverse proportion of $\mathrm{CO}_{2}$ generation level and $\mathrm{O}_{2}$ concentration level increased the rate of complete combustion (Choi et al., 2015). Looking at the trend with ventilation, in the case of $\mathrm{A} 1, \mathrm{~A} 3, \mathrm{~B} 1$, and $\mathrm{B} 2$ where $\mathrm{CO}_{2}$ generation amount was more than about $1.5 \%$ at 10 minutes, reduction rates were up to $44.1 \%$, $50.0 \%, 51.3 \%$, and $53.6 \%$ after the ventilation fan was operated (Fig. 5. Dotted line). On the other hand, A2 and $\mathrm{B} 3$, in which $\mathrm{CO}_{2}$ generation amount was around $1 \%$, gradually decreased after 12 minutes and then remained constant at about $0.5 \%$. Similar to the aforementioned trend of $\mathrm{CO}$, such a result may be caused by the phenomenon that the rate of complete combustion increased due to the inflow air.

In the case with ventilation, the amount of $\mathrm{NO}_{\mathrm{x}}$ increased rapidly in all samples until the initial 1 minute. Even after 1 minute, the $\mathrm{NO}_{\mathrm{x}}$ generation amount of A1, A3, and B2 showed a tendency to increase continuously to a maximum of $29 \mathrm{ppm}$ (20 minutes), 47 ppm (20 minutes), and $36 \mathrm{ppm}$ (20 minutes), respectively (Fig. 6. Solid line). It is judged that the incomplete combustion continues during the combustion process of A1, A3, and B2 (Jeoung et al., 2020). On the other hand, the amount of $\mathrm{NO}_{\mathrm{x}}$ generated in $\mathrm{A} 2$, $\mathrm{B} 1$, and B3 appeared relatively constant after $1 \mathrm{mi}-$ nute, with a maximum of $18 \mathrm{ppm}$ (20 minutes), 17 ppm (20 minutes), and 9 ppm (20 minutes), respectively. In the case with ventilation of $\mathrm{A} 1, \mathrm{~A} 3$, and $\mathrm{B} 2$, the amount of $\mathrm{NO}_{\mathrm{x}}$ generated continues to increase, similar to the closed condition, showing a maximum of $17 \mathrm{ppm}$ (10 minutes), 35 ppm (10 minutes), and $27 \mathrm{ppm}$ (10 minutes), respectively, and after the ventilation fan was turned on, the reduction rates were up to about $47.1 \%, 31.4 \%$, and $40.7 \%$ (Fig. 6. Dotted line). According to Feng et al. (2010), the higher air inflow in fuel combustion can lower the ratio of $\mathrm{NO}_{\mathrm{x}}$. In the case of $\mathrm{A} 2, \mathrm{~B} 1$, and $\mathrm{B} 3$, the case without ven- 
Evaluation of the Amount of Gas Generated through Combustion of Wood Charcoal and

Agglomerated Charcoal Depending on Air Ventilation

tilation were similar, and the reduction rates were up to about $40.0 \%, 50.0 \%$ and $62.5 \%$. The amount of $\mathrm{NO}_{\mathrm{x}}$ generated, on average, was $26.0 \mathrm{ppm}$ (20 minutes) without ventilation and $10.7 \mathrm{ppm}$ (20 minutes) with ventilation, which was lower than 90 ppm, which is the emission limit, satisfying the emission limit.

\section{CONCLUSION}

In this study, the characteristics of fuel were analyzed for the charcoal and agglomerated charcoal available in Korea. A model space that simulated the usage environment was created to measure the amount of flue gas generated during the combustion and to evaluate the ventilation rate by classifying it into the closed conditions and ventilated conditions. As a result of analyzing the fuel characteristics of the charcoal (A1, A2, and A3) and the agglomerated charcoal (B1, B2, and B3), all charcoal products satisfied the quality standard, but the agglomerated charcoal product B2 did not satisfy the quality standard. With the combustion characteristics of closed and ventilated conditions, the charcoal (A1, A2, and A3) had a longer ignition time than the agglomerated charcoal (B1, B2, and $\mathrm{B} 3$ ). In particular, for the ignition time of $\mathrm{B} 1$ and B2 containing igniting agents in the agglomerated charcoal, it was confirmed that the agent greatly shortened the time. In addition, in most of the samples, the content of volatile substances was higher in the closed condition than in the ventilated condition.

As a result of the comparison of the flue gas generation, consisted of $\mathrm{CO}, \mathrm{CO}_{2}, \mathrm{NO}_{\mathrm{x}}$, and $\mathrm{O}_{2}$, the concentration of $\mathrm{O}_{2}$ continued to decrease without ventilation, and recovered to about $91.2 \sim 96.0 \%$ of the initial $\mathrm{O}_{2}$ concentration level with ventilation. In the case of $\mathrm{CO}$, the concentration wasin the range of 1390 to $4703 \mathrm{ppm}$ with ventilation. In the case with ventilation, it was confirmed that the concentration of $\mathrm{CO}$ dropped rapidly after the ventilation fan was turned on, and then gradually decreased due to the equilibrium between the amount of $\mathrm{CO}$ production and the amount of ventilation.

The amount of $\mathrm{CO}_{2}$ generated was similar to that of $\mathrm{CO}$ generated in both with and without ventilation, which was inversely proportional to the amount of $\mathrm{O}_{2}$ generated. In the case of $\mathrm{NO}_{\mathrm{x}}$, the amount of flue gas generated in a sample that continued incomplete combustion increased steadily, but the amount of flue gas for the samples with complete combustion showed a constant amount.

Based on the result obtained through this study, the amount of ventilation and the amount of flue gas generated through combustion in a specific space, the amount of ventilation required for cooking food using charcoal and agglomerated charcoal in the future can be identified and can be utilized as basic data for health hazard evaluation.

\section{ACKNOWLEDGMENT}

This research was supported by the Research Program (FP0900-2019-02) of the National Institute of Forest Science (NIFoS, Republic of Korea).

\section{REFERENCES}

Chia, C.H., Joseph, S.D., Rawal, A., Linser, R., Hook, J.M., Munroe, P. 2014. Microstructural characterization of white charcoal. Journal of Analytical and Applied Pyrolysis 109: 215-221.

Choi, Y.S., Euh, S.H., Oh, K.C., Kim, D.H., Oh, J.H. 2015. A study on combustion characteristics in terms of the type of fuel supply device (feeder) of a wood pellet boiler. Journal of Energy Engineering 24(2): 120-128.

Huang, H.L., Lee, W.M.G., Wu, F.S. 2016. Emissions of air pollutants from indoor charcoal barbecue. Journal of Hazardous Materials 302: 198-207. 
Jelonek, Z., Drobniak, A., Mastalerz, M., Jelonek, I. 2020. Environmental implications of the quality of charcoal briquettes and lump charcoal used for grilling. Science of the Total Environment 747: 141267.

Jeoung, T.Y., Yang, S.M., Kang, S.G. 2020. Study on foel specificity and harmful air pollutants factor of agglomerated wood charcoal. Journal of the Korean Wood Science and Technology 48(2): 253-266.

Jo, T.S., Choi, J.W., Lee, O.K. 2007. Physicochemical changes of woody charcoals prepared by different carbonizing temperature. Journal of the Korean Wood Science and Technology 35(3): 53-60.

Ju, Y.M., Lee, H.W., Kim, A.R., Jeong, H.S., Chea, K.S., Lee, J.J., Ahn, B.J., Lee, S.M, 2020. Characteristics of carbonized biomass produced in a manufacturing process of wood charcoal briquettes using an open-hearth kiln. Journal of the Korean Wood Science and Technology 48(2): 181-195.

Kabir, E., Kim, K.H., Yoon, H.O. Ahn, J.W., Hong, O.F., Sohn, J.R. 2010. Barbecue charcoal combustion as a potential source of aromatic volatile organic compounds and carbonyls. Journal of Hazardous Materials 174(1-3): 492-499.

Korea Forest Service. 2018a. Act on the sustainable us of timbers. Act. No. 15391.

National Institute of Forest Science. 2018. Standard and specification of wood products. Notification No. 2018-8.

Korea Forest Service. 2018b. Regulation on promotion of use and supply of forest biomass energy. Notification No. 2018-72.

Lee, D.Y., Kim, B.R. 2010. Analysis of functional characteristics of the commercial wood charcoal in Korea. Journal of the Korean Wood Science and Technology 38(6): 480-489.

Lee, J.J., Kim, E.J., Lee, S.M., Ju, Y.M., Ahn, B.J. 2016. Upgrading of the hydrophobicity of Larix Kaempferi and Liriodendron tulipifera via torrefaction. New\&Renewable Energy 12(4): 70-76.

Pandey, S.K., Kim, K.H., Kang, C.H., Jung, M.C., Yoon, H. 2009. BBQ charcoal as an important source of mercury emission. Journal of Hazardous Materials 162(1): 536-538.

Ren, F., Li, Z., Chen, Z., Xu, Z., Yang, G. 2010. Experimental investigations into gas/particle flows in a down-fired boiler: influence of the vent air ratio. Energy \& fuels 24(3): 1592-1602.

The minister of environment, 2020, Enforcement decree of the clean air conservation act. Act. No. 859. Vicente, E.D., Vicente, A., Evtyugina, M., Carvalho, R., Tarelho, L.A.C., Oduber, F.I., Alves, C. 2018. Particulate and gaseous emissions from charcoal combustion in barbecue grills. Fuel Processing Technology 176: 296-306. 
Evaluation of the Amount of Gas Generated through Combustion of Wood Charcoal and

Agglomerated Charcoal Depending on Air Ventilation

\title{
APPENDIX
}

\author{
(Korean Version)
}

\section{숯과 성형숯의 연소를 통해 배출되는 가스 발생량 및 실내공간 환기량 평가}

초록 : 본 연구는 국내 숯불구이 음식점의 화구당 평균 공간을 바탕으로 제작된 모형 연소방을 이용하여 국내에서 유통되고 있는 숯과 성형숯의 연소 조건에 따라 발생하는 연소 가스와 연소 특성에 관한 연구를 수행하였다. 각각 3종의 숯과 성형숯의 연료 특성과 연소 특성을 분석하였다. 또한, 밀폐 조건과 환기 조건으로 구분하고 총 20 분의 연소과정 동안 발생하는 $\mathrm{CO}$, $\mathrm{CO}_{2}, \mathrm{NO}_{\mathrm{x}}$ 의 농도와 $\mathrm{O}_{2}$ 농도의 변화량을 분석하였다. 분석 결과, $\mathrm{CO}$ 의 발생량은 밀폐 조건에서 $1390 \sim 4703 \mathrm{ppm}$ 의 범위로 측정되었으며, 환기 시 약 $29.8 \% ~ 57.4 \%$ 의 환기율을 보였다. $\mathrm{CO}_{2}$ 는 밀폐 조건에서 $1.34 \% ~ 2.42 \%$ 의 범위로 나타났으며, 환기 시 특정 시점( 10 분)에 $1.5 \%$ 이상 발생한 시료에서 $44.1 \% ~ 53.6 \%$ 의 환기율을 보였다. $\mathrm{NO}_{\mathrm{x}}$ 의 발생량은 밀폐 조건의 경우 불완전 연소로 인해 지속적으로 발생량이 증가하여 $29 \mathrm{ppm} 47 \mathrm{ppm}$ 의 범위로 발생하는 경우와 특정 시점(1분) 이후 $9 \mathrm{ppm} \mathrm{18} \mathrm{ppm의}$ 범위로 비교적 일정한 발생량을 보이는 경우로 나뉘었다. 환기 조건의 $\mathrm{NO}_{\mathrm{x}}$ 배출량은 밀폐 조건과 유사한 경향을 보였으며, 최대 $62.5 \%$ 의 환기율을 보였다. 따라서, 본 연구 결과를 바탕으로 숯과 성형숯의 사용환경을 모사하여 인체 유해성 평가에 활용 가능할 것으로 판단된다.

\section{1. 서 론}

목재의 지속가능한 이용에 관한 법률에서 지정한 목재제품인 숯과 성형숯은 국립산림과학원 고시 제2018-8호 '목재제품의 규격과 품질기준'의 ‘부속서 14 '와 ‘부속서 15 '에 정의되어 있다(Korea Forest Service, 2018). 솣은 백탄과 흑탄으로 나뉘며, 정련 후 가마외 소화법(백탄)과 가마내 소화법(흑탄)에 따라 구분된다. 성형숯은 결합제 및 착화제의 유무와 성형 형태에 따라 톱밥성형탄, 숯가루성형탄, 구멍탄착화용 성형탄으로 구분된다(National Institute of Forest Science, 2018).

숯과 성형숯은 목재보다 에너지밀도가 높고 장시간 연소하며 연기가 적게 발생하는 장점이 있다(Kabir et al., 2010; Huang et al., 2016). 이외에도 나무의 껍질이나 톱밥, 코코넛 껍질 등과 같은 다양한 원료를 이용하여 제작할 수 있고 석탄보다 상대적으로 황과 수은의 함량이 낮으며, 저장과 보관이 용이하다는 장점이 있다(Jelonek et al., 2020; Vicente et al., 2018). 이러한 장점 때문에 숯과 성형숯은 요리에 사용되며, 특히 숯불에 고기를 조리해 먹는 바비큐 활동에서 실·내외할 것 없이 광범위하게 사용되고 있다. 하지만 숯을 점화하는 과정과 고온의 숯불을 통해 고기를 바비큐 과정에서 발생하는 배출물은 공기의 질을 저하할 수 있고 음식에 흡수될 수 있어서 소비자가 고기를 섭취하거나 호흡 과정을 통해 오염물질에 쉽게 노출된다 (Kabir et al., 2010; Huang et al., 2016).

'목재제품의 규격과 품질기준' 고시에서는 솣과 성형숯의 품질 항목으로 함수율, 회분, 고위 발열량, 고정탄소와 같은 연료적 특성을 명시하고 있다. 또한 성형솣은 결합제와 착화제와 같은 화학물질이 첨가되므로 추가적으로 납, 비소, 수은, 카드뮴과 같은 5대 중금속 항목과 크롬, 구리, 니켈, 황과 같은 항목이 품질항목에 포함되어 있다(Korea Forest Service, 2018). 그러나, 중금속 항목은 제품의 사용 전 금속 원소 함량을 나타낸 것으로 실제 소비자가 제품을 구이용으로 사용했을 경우 배출되는 연소가스의 종류 및 유해성에 관한 기준은 부족한 실정이다.

숯 및 성형숯 연소 시 배출물질을 분석한 국외 선행연구들의 결과에서는 숯 연소로 인한 배출가스 중 상대적으로 수은 농도가 높다고 보고되었고(Pandey et al., 2009), 발암성 물질인 폼알데하이드, 아세트알데하이드 등도 일부 제품의 경우에 검출된 것으로 보고되었다(Huang et al., 2016). 이외에도 호흡 과정에서 인체에 유입 가능한 미세 입자와 일산화탄소, 이산화탄 소, 질소산화물 등이 숯불의 연소과정에서 지속적으로 발생한다고 보고되었다(Kabir et al., 2010). 종합해보면 숯과 성형숯의 연소로부터 발생되는 가스 성분은 다양한 것으로 판단되며, 이와 같은 결과들은 제품의 사용 안전성을 판단평가함에 있어서 중요한 근거자료가 될 것으로 기대된다. 그러나 국내 유통 중인 숯 및 성형숯 제품의 경우는 아직 이러한 사용 시 발생되는 연소가스의 종류와 농도에 대한 체계적인 자료 구축이 미비한 상황이다.

따라서 본 연구에서는 숯과 성형솣을 구이용으로 사용하는 경우에 한하여 연소 시 배출되는 가스 $\left(\mathrm{CO}, \mathrm{CO}_{2}, \mathrm{NO}_{\mathrm{x}}, \mathrm{O}_{2}\right)$ 의 농도를 실시간으로 측정하고, 숯불을 사용하는 국내 음식점 환경을 고려하여 배기구의 환기량에 따른 가스 농도 변화를 비교 및 분석하고자 하였다. 


\section{2. 재료 및 방법}

\section{1. 공시재료}

본 연구에서는 국내에서 유통 중인 솣과 성형솣을 각각 3종씩 구매하여 공시재료로 사용하였다. 숯은 백탄 2종(A1, A2)과 흑탄 1종(A3)으로 성형숯은 숯가루성형탄 1종(B1), 구멍탄착화용 성형탄 1종(B2), 톱밥성형탄 1종(B3)을 사용하였으며, 제품 의 품질표시에 구매 당시 제품의 특성은 Table 1 과 같다.

\section{2. 연료 특성 분석}

공시재료의 연료적 특성을 비교하기 위해 공업분석을 수행하였고, 원소 함량 및 발열량을 측정하였다. 자세한 측정 방법은 $\mathrm{Ju}$ 등(2020)에서 찾을 수 있다. 발열량은 봄베형 열량계(6400 Automatic Isoperibol Calorimeter, Parr Instrument company, USA)를 이용하여 시료의 고위발열량을 측정하였으며, 분석 시료는 약 $0.5 \mathrm{~g}$ 의 분말 시료를 정칭하여 사용하였다. 공업분석은 수분회분측정기(PrepASH229, precisa, Swiss)를 사용하여 시료의 함수율, 휘발분, 회분 함량을 분석하였으며, 고정탄소는 식 (1)을 통해 계산되었다.

$$
\mathrm{FC}=100-(\mathrm{MC}+\mathrm{VM}+\mathrm{ASH})
$$

FC=Fixed carbon $(\%), \quad \mathrm{MC}=$ Moisture content $(\%), \quad \mathrm{VM}=$ Volatile matter $(\%), \quad$ Ash=Ash content $(\%)$

원소 함량의 분석에는 표준물질 2693(NIST, USA)을 사용하였고 원소분석기(vario MICRO cube elemental analyzer, elementar, Germany)를 이용하여 탄소, 수소, 질소, 황 함량을 분석하였으며, 산소 함량은 식 (2)에 의해 계산되었다.

$$
\mathrm{O}=100-(\mathrm{C}+\mathrm{H}+\mathrm{N}+\mathrm{S})
$$

$\mathrm{O}=$ Oxygen content $(\%), \quad \mathrm{C}=$ Carbon content $(\%), \quad \mathrm{H}=$ Hydrogen content $(\%)$,

$\mathrm{N}=$ Nitrogen content $(\%), \quad \mathrm{S}=$ Sulfur content $(\%)$

\section{3. 사용환경 모사 연소 실험}

숯과 성형숯의 연소 실험을 위해 제작된 모형 연소방의 모식도는 Fig. 1과 같다. 모형 연소방은 일반적인 숯불 음식점의 4 인 테이블 공간을 가정하여 가로×세로×높이는 $1.5 \times 1.5 \times 2 \mathrm{~m}$ 로 설계하였으며, 내부 부피는 약 $3.96 \mathrm{~m}^{3}$ 으로 제작되었다. 탁자의 높이는 $720 \mathrm{~mm}$ 이며, 로스터와 배기구 사이 간격은 $120 \mathrm{~mm}$, 배기구(내부 직경: $95 \mathrm{~mm}$, 높이: $1 \mathrm{~m}$ )와 테이블 사이 간격은 $120 \mathrm{~mm}$ 으로 제작하였다. 계측장비인 풍속계와 가스측정 프로브는 배기구의 중앙(높이 방향)에 설치하였으며, 배기구 상단에는 환기팬을 설치하고 팬속도 조절기를 통해 환기팬의 속도를 조절했다. 가스측정 프로브로 측정된 배기속도는 $0.3 \mathrm{~m} / \mathrm{s}$ 였으며, 풍량은 $0.008 \mathrm{~m}^{3} / \mathrm{s}$ 였다. 환기팬 가동 시 모형 연소방 내부의 공기 순환을 위해 공기 압축기로 외부 공기를 직경 $6 \mathrm{~mm}$ 의 관을 통해 $25 \mathrm{~L} / \mathrm{min}$ 으로 일정하게 유입시켰다. 가스 샘플링 관은 모형 연소방 중간 위치인 $1 \mathrm{~m}$ 에 설치하였다.

숯을 사용하는 일반적인 국내 음식점의 사용환경을 모사한 실험 과정은 Fig. 2 와 같다. 외부 숯불 점화기에서 숯을 점화시킨 후 구이용으로 사용하는 상황을 묘사하기 위해 우선 모형 연소방 외부에서 시험편을 점화시킨 후 10 분간 연소시켰다(Fig. 2 (1). 이후 시험편을 모형 연소방에 투입하고 밀폐한 후 가스 발생량 및 온도를 측정하였다. 첫 번째로 모형 연소방 내부에 연소 가스를 누적시키기 위해 10 분간 시험편을 연소시켰다(Fig. 2 (2). 두 번째로 환기율을 평가하기 위해 밀폐된 경우와 환기팬을 가동한 경우로 나누어 10 분간 연소실험을 진행하였다(Fig. 2 (3-1, 2). 실험 종료 후 30분간 연소가 진행된 시험편의 무게를 측정하고 대기에서 자연 연소시킨 후 남아있는 잔여물의 무게를 측정하였다.

\section{4. 연소 가스 측정}

숯과 성형숯의 연소로부터 발생되는 가스 성분의 실시간 배출량은 연소가스 측정기(Testo 350XL, Testo, Germany)를 통해 측정하였다. 배기구 중앙에 설치된 가스측정 프로브로 밀폐조건과 환기조건에서 $\mathrm{CO}, \mathrm{CO}_{2}, \mathrm{NO}_{\mathrm{x}}, \mathrm{O}_{2}$ 성분의 가스발생량을 20 분간 15 초 간격으로 측정하였다. 
Evaluation of the Amount of Gas Generated through Combustion of Wood Charcoal and

Agglomerated Charcoal Depending on Air Ventilation

\section{3. 결과 및 고찰}

\section{1. 연료 특성}

숯과 성형숯의 연료 특성을 분석한 결과는 Table 2 와 같다. 공업분석 결과, 함수율의 경우 숯 제품인 A1 A3은 $0.9 ~ 1.9 \%$ 로 나타났으며, 성형숯 제품인 B1 B3은 2.6 3.0\%로 모든 제품에서 국립산림과학원 고시 제2018-8호 '목재제품의 규격과 품질기 준'의 부속서14(성형숯)와 부속서15(숯)의 기준에 부합하는 결과를 나타냈다(National institute of forest science, 2018). 휘발성 화합물은 B1에서 $43.3 \%$ 로 가장 높은 함량을 보였으며, $\mathrm{A} 2$ 에서 $5.4 \%$ 로 가장 낮은 함량이 나타났다. 회분 함량은 B2가 $39.3 \%$ 로 구멍탄착화용 성형탄의 품질기준인 $17 \%$ 보다 약 $22.7 \%$ 높게 나타나 품질기준을 만족하지 못했으며, 이는 성형을 위해 사용된 첨가물 외에도 원료의 처리 과정에서 휽과 같이 제품의 품질을 저하시킬 수 있는 물질이 많이 포함되어 나타난 현상으로 보인다(Ju et al., 2020; Jeoung et al., 2020). 반면에, 다른 제품에서는 모두 품질기준을 만족하는 결과를 보였다. 고정탄소 함량은 숯의 경우 품질기준이 존재하지 않았으며, $\mathrm{A} 1, \mathrm{~A} 2, \mathrm{~A} 3$ 에서 각각 $86.0 \%, 90.4 \%, 57.7 \%$ 로 나타났다. 성형숯의 경우에는 B1과 B3는 품질기준을 만족하였지만 B2에서 $26.8 \%$ 로 품질기준보다 약 $23.2 \%$ 낮게 나타났다. 원소함량 분석 결과, 탄소 함량은 A2에서 $97.4 \%$ 로 가장 높았고 B2에서 $40.6 \%$ 로 가장 낮으며, 높은 함량일수록 수소, 질소, 산소 함량은 낮아지는 경향을 보였다. 이는 선행된 연구에서도 목탄 내 탄소가 증가할수록 수소와 산소는 감소한다고 보고되었다(Jo et al., 2007; Lee et al., 2010). 이와 반대로 고위발열량과는 비례하는 관계를 보였으며, 이는 탄화 정도에 따라 높은 결합 에너지의 C-C 결합이 증가하기 때문이다(Lee et al., 2016). 황 함량의 경우 $\mathrm{A} 2$ 와 B2에서 각각 $0.01 \%$ 와 $0.05 \%$ 로 나타났다. 고위발열량은 회분과 고정탄소의 경우와 마찬가지로 $\mathrm{B} 2$ 에서 품질기준인 $5,500 \mathrm{kcal} / \mathrm{kg}$ 을 만족시키지 못하는 결과를 보였다.

\section{2. 점화시간 및 연소 시 중량 변화}

모형 연소방을 통해 수행한 밀폐 조건과 환기 조건의 연소 특성은 Table 3 과 같다. 점화시간은 숯과 성형숯의 종류, 환기 및 착화제 유무에 따라 결과가 상이하였다. 평균적으로 숯(A1, A2. A3)의 경우 성형숯에 비해 점화시간이 긴 결과를 보였으며, 낮은 휘발성 화합물로 인해 점화에 유리한 저 분자량 화합물이 부족하여 나타나는 것으로 사료된다(Chia et al., 2014). 특히, 성형솣 중에서는 착화제가 첨가된 $\mathrm{B} 1$ 과 $\mathrm{B} 2$ 의 경우 점화시간이 3 분으로 가장 짧았다. 그러나 착화제가 포함되지 않은 $\mathrm{B} 3$ 의 경우 점화시간이 15 분으로 $\mathrm{B} 1, \mathrm{~B} 2$ 에 비해 약 5 배 길게 나타났으며, 이를 통해 착화제에 의해 성형숯의 점화 성능 크게 향상됨을 확인하였다.

밀폐 조건에서 성형숯 및 숯이 연소될 경우 B2의 경우를 제외한 모든 시료에서 휘발물질의 함량이 환기 조건보다 상대적으로 높았다. 특히, $\mathrm{B} 1$ 의 경우 밀폐 및 환기 조건에서 모두 휘발물질의 함량이 가장 높았으며, 각각 $68.9 \%$ 와 $67.8 \%$ 로 나타났다. 이후 대기에 방치하여 연소 후 잔여물의 함량은 전반적으로 밀폐 조건이 높은 결과를 보였으나, 일부 제품의 경우 경향이 상이하였다. 이는 밀폐 시 연소에 요구되는 산소 공급이 제한됨에 따라 불완전연소가 될 가능성이 높아지고, 이에 따라 연소 후 잔여물 양이 환기 조건보다 증가한 것으로 사료된다. 가장 낮은 잔여물 함량은 환기 조건 하에서 연소한 $\mathrm{A} 1, \mathrm{~A} 3$ 에서 각각 $6.1 \%, 3.2 \%$ 로 나타났다.

\section{3. 실시간 연소가스 배출량}

숯과 성형숯의 연소를 통해 배출되는 $\mathrm{CO}, \mathrm{CO}_{2}, \mathrm{NO}_{\mathrm{x}}, \mathrm{O}_{2}$ 의 농도를 실시간으로 측정한 결과는 Fig. $3,4,5,6$ 과 같으며, 각 $\mathrm{CO}$ 와 $\mathrm{NO}_{\mathrm{x}}$ 의 유해성 기준은 Table. 4 와 같다. 밀폐 조건에서 $\mathrm{O}_{2}$ 의 농도는 Fig. 3 의 실선과 같다. 평균적으로 $21.04 \%(0$ 분 $)$ 에서 $17.5 \%$ 까지 감소하였다. 초기보다 시간이 지남에 따라 지속해서 감소하였으며, 20 분일 때 $\mathrm{A} 1, \mathrm{~A} 2, \mathrm{~A} 3, \mathrm{~B} 1, \mathrm{~B} 2, \mathrm{~B} 3$ 에서 각각 최대 $18.8 \%, 14.8 \%, 20.0 \%, 17.8 \%, 17.0 \%, 11.4 \%$ 만큼 감소하였다(Fig. 3). 환기 조건의 $\mathrm{O}_{2}$ 농도는 Fig. 3 의 점선과 같으며 환기팬 가동 후 $\mathrm{O}_{2}$ 농도가 급격히 증가하였으며, 본 실험 범위 내에서 초기 농도의 $91.2 \sim 96.0 \%$ 까지 회복하는 결과를 나타냈다.

$\mathrm{CO}$ 의 경우 밀폐 조건은 Fig. 4 실선과 같으며, 연소시간이 지남에 따라 농도가 지속적으로 증가하는 경향을 보였다. 성형숯 (B1, B2, B3)은 연소 시 솣보다 상대적으로 높은 CO 농도를 나타냈으며, 성형숯 중 B1에서 가장 높은 $4703 \mathrm{ppm}(20$ 분), 숯 중 $\mathrm{A} 2$ 에서 가장 낮은 $1390 \mathrm{ppm}$ 을 나타냈다. 환기 조건에서는 모든 시험편에서 환기팬 가동 시점인 10 분 후에 $\mathrm{CO}$ 의 농도가 급격히 감소하다가 완만해지는 경향을 보였다(Fig. 4. 점선). 이는 환기로 인하여 모형연소방 내 농축된 $\mathrm{CO}$ 가 밖으로 배출되고 시간이 지남에 따라 유입된 공기를 통해 완전연소가 촉진되어 CO 생성량이 감소해 나타난 경향으로 사료된다. 특히, $\mathrm{B} 3$ 의 경우 환기 조건 하 $\mathrm{CO}$ 농도가 최대 $2102 \mathrm{ppm}$ 에서 $896 \mathrm{ppm}$ 으로 감소하면서 가장 큰 환기율(약 $57.4 \%)$ 을 나타냈고 반면 B1에서 29.8\%로 가장 낮은 환기율을 나타내었다. 또한 $\mathrm{CO}$ 농도는 평균적으로 밀폐 조건에서 $3092.7 \mathrm{ppm}$ (20분), 환기 
조건은 $1189.2 \mathrm{ppm}(20$ 분 $)$ 으로 나타나 배출허용기준 농도인 $200 \mathrm{ppm}$ 을 만족시키지 못하는 결과를 보였다. 이는 숯과 성형숯을 사용할 때 밀폐된 공간보다는 환기가 되는 공간이 요구되고 환기량이 $0.008 \mathrm{~m}^{3} / \mathrm{s}$ 보다 높은 환경에서 사용해야 한다는 것을 나타낸다.

$\mathrm{CO}_{2}$ 의 경우는 농도가 $2.5 \%$ 이하로 낮은 범위였으나 밀폐 조건과 환기 조건 모두 $\mathrm{CO}$ 의 농도 변화 경향과 유사하게 나타났다 (Fig. 5). 밀폐 조건에서 $\mathrm{A} 1, \mathrm{~A} 2, \mathrm{~A} 3, \mathrm{~B} 1, \mathrm{~B} 2, \mathrm{~B} 3$ 의 $\mathrm{CO}_{2}$ 발생량은 각각 $2.23 \%, 1.69 \%, 2.42 \%, 2.07 \%, 2.03 \%, 1.34 \%$ 로 나타났으며(Fig. 5. 실선), 앞서 언급한 $\mathrm{O}_{2}$ 농도의 감소량과 비례하는 결과를 보였다. 선행 연구에서도 $\mathrm{CO}_{2}$ 발생량과 $\mathrm{O}_{2}$ 농도의 반비례는 완전연소의 비율을 증가시킨다고 보고되었다(Choi et al., 2015). 환기 조건의 경향을 살펴보면 특정 시점(10분)에 $\mathrm{CO}_{2}$ 발생량이 약 $1.5 \%$ 이상인 $\mathrm{A} 1, \mathrm{~A} 3, \mathrm{~B} 1, \mathrm{~B} 2$ 의 경우 환기팬 가동 후 최대 $44.1 \%, 50.0 \%, 51.3 \%, 53.6 \%$ 의 환기율을 보였다 (Fig. 5. 점선). 반면에 $\mathrm{CO}_{2}$ 발생량이 $1 \%$ 전후로 발생된 $\mathrm{A} 2$ 와 $\mathrm{B} 3$ 은 12 분 이후에 완만하게 낮아지다가 약 $0.5 \%$ 로 일정하게 유지되는 경향을 보였다. 이는 앞서 언급한 $\mathrm{CO}$ 의 경향과 유사하게 유입된 공기로 인해 완전연소의 비율이 높아져서 나타나는 현상 때문으로 판단된다.

$\mathrm{NO}_{\mathrm{x}}$ 의 발생량은 밀폐 조건의 경우 초기 1 분까지 모든 시료에서 급격히 증가하는 경향을 보였다. 1 분 이후에도 $\mathrm{A} 1, \mathrm{~A} 3$, $\mathrm{B} 2$ 의 $\mathrm{NO}_{\mathrm{x}}$ 발생량은 각각 최대 $29 \mathrm{ppm}(20$ 분), $47 \mathrm{ppm}$ (20분), $36 \mathrm{ppm}$ (20분)까지 지속적으로 증가하는 경향을 보였다(Fig. 6. 실선). 이는 $\mathrm{A} 1, \mathrm{~A} 3, \mathrm{~B} 2$ 의 연소 과정동안 불완전 연소가 지속되어 나타나는 것으로 판단된다(Jeoung et al., 2020). 이에 반해 $\mathrm{A} 2, \mathrm{~B} 1, \mathrm{~B} 3$ 의 $\mathrm{NO}_{\mathrm{x}}$ 발생량은 1 분 이후 비교적 일정하게 나타났으며, 각각 최대 $18 \mathrm{ppm}(20$ 분), $17 \mathrm{ppm}(20$ 분), $9 \mathrm{ppm}(20$ 분) 으로 나타났다. 환기 조건의 $\mathrm{A} 1, \mathrm{~A} 3, \mathrm{~B} 2$ 의 경우도 밀폐 조건과 유사하게 $\mathrm{NO}_{\mathrm{x}}$ 발생량이 지속하여 증가해 각각 최대 $17 \mathrm{ppm}(10$ 분), $35 \mathrm{ppm}$ (10분), $27 \mathrm{ppm}(10$ 분)으로 나타나다가 환기팬 가동 후 최대 약 $47.1 \%, 31.4 \%, 40.7 \%$ 의 환기율을 보였다(Fig. 6. 점선). 이는 Feng et al. (2010)에 따르면 연료의 연소에서 공기의 유입이 높아지면 $\mathrm{NO}_{\mathrm{x}}$ 의 비율이 낮아질 수 있다고 보고했다. $\mathrm{A} 2, \mathrm{~B} 1, \mathrm{~B} 3$ 의 경우도 밀폐 조건과 유사하였으며, 최대 약 $40.0 \%, 50.0 \%, 62.5 \%$ 의 환기율을 보였다. $\mathrm{NO}_{\mathrm{x}}$ 의 발생량은 평균적으 로 밀폐 조건은 $26.0 \mathrm{ppm}(20$ 분), 환기 조건은 $10.7 \mathrm{ppm}$ (20분)으로 나타나 배출허용기준인 $90 \mathrm{ppm}$ 보다 낮게 나타나 배출허용기 준을 만족했다.

\section{4. 결 론}

본 연구에서는 국내에서 유통 중인 숯과 성형숯에 대해 연료 특성을 분석하고 사용환경을 모사한 공간을 제작하여 연소 시 발생하는 가스 발생량을 측정하고 밀폐 조건과 환기 조건으로 분류하여 환기율을 평가하였다. 숯(A1, A2, A3)과 성형숯(B1, $\mathrm{B} 2, \mathrm{~B} 3)$ 의 연료 특성을 분석한 결과, 숯은 모든 제품이 품질기준을 만족하였으나 성형솣 제품인 B2에서 품질기준을 만족시키지 못했다. 밀폐 조건과 환기 조건의 연소 특성을 살펴보면 숯(A1, A2, A3)이 성형숯(B1, B2, B3)에 비해 점화시간이 길었고 특히, 성형숯에 착화제가 포함된 제품인 $\mathrm{B} 1, \mathrm{~B} 2$ 의 점화시간이 크게 단축되는 것을 확인하였다. 또한, 대부분의 시료에서 환기 조건보다 밀폐 조건에서 휘발 물질의 함량이 높게 나타났다.

$\mathrm{CO}, \mathrm{CO}_{2}, \mathrm{NO}_{\mathrm{x}}, \mathrm{O}_{2}$ 성분의 연소가스 발생량 비교를 통해 나타난 결과로 밀폐 조건에서 $\mathrm{O}_{2}$ 의 농도는 지속해서 감소하였고 환기 조건에서는 초기 $\mathrm{O}_{2}$ 농도에 약 91.2 96.0\%까지 회복했다. $\mathrm{CO}$ 의 경우에는 밀폐 조건에서 1390 4703 ppm의 범위로 발생하였다. 환기 조건의 경우 $\mathrm{CO}$ 의 농도가 환기팬 가동 후 급격히 떨어지다가 $\mathrm{CO}$ 의 생성량과 환기량의 평형으로 인해 완만해 지는 결과를 확인하였다. $\mathrm{CO}_{2}$ 의 발생량은 밀폐 조건과 환기 조건 모두에서 $\mathrm{CO}$ 의 발생량 경향과 유사하게 나타났으며, $\mathrm{O}_{2}$ 의 발생량과 반비례하는 결과를 보였다. $\mathrm{NO}_{x}$ 의 경우 불완전 연소가 지속되는 시료는 발생량이 꾸준하게 증가하였지만 비교적 완전 연소가 진행된 시료의 경우 일정한 발생량을 보였다.

본 연구를 통해서 얻어진 결과인 특정 공간에서 연소를 통해 생성되는 가스의 발생량과 환기량을 바탕으로 향후 실내에서 숯과 성형숯을 이용하여 음식 조리 시 필요한 환기량을 파악할 수 있고 나아가 인체 유해성 평가에 대한 기초자료로써 활용 가능할 것으로 판단된다. 